\title{
Influence of anterior teeth inclination on the strength of incisors with post and cores
}

\section{Wpływ inklinacji zębów przednich na wytężenie siekaczy odbudowanych wkladami koronowo-korzeniowymi}

\author{
Beata Dejak', Andrzej Mtotkowski ${ }^{2}$ \\ ${ }^{1}$ Zakład Protetyki Stomatologicznej, Uniwersytet Medyczny w Lodzi \\ Department of Prosthodontics, Medical University in Lodz \\ Head: prof. dr hab. n. med. Beata Dejak \\ ${ }^{2}$ Katedra Wytrzymałości Materiałów i Konstrukcji, Politechnika Lódzka, Poland \\ Chair of Strength of Materials and Constructions, Lodz University of Technology \\ Head: prof. dr hab. inż. Tomasz Kubiak
}

\section{KEY WORDS:}

incisor inclination, post and cores, finite element analysis, modified von Mises stresses, contact tensile and shear stresses

\section{Summary}

Introduction. Labially inclined anterior teeth are an aesthetic and biomechanical problem. Will the prosthetic restoration of a damaged incisor whose root is inclined labially withstand chewing forces?

Aim of the study. To estimate the influence of anterior teeth inclination on the strength of incisors reinforced with post and cores.

Material and methods. The experiment was conducted by using FEA with contact elements. 3-D models of maxillary central incisors were created: model $A$ - tooth, model B - tooth with a post and core. The axes of $A$ and $B$ models were positioned as follows: 1 - retroclined, 2 normally inclined, 3 - labially inclined at 10\%, $30 \%$ and $50 \%$ angle of inclination, respectively. Each model was subjected to a force of $100 \mathrm{~N}$. The modified von Mises failure criterion ( $m v M$ ) was used to evaluate the strength of the tooth structures and cement. Contact stresses at the

\section{HASŁA INDEKSOWE:}

nachylenie siekaczy, wkłady koronowo-korzeniowe, metoda elementów skończonych, zmodyfikowane naprężenia Misesa, kontaktowe rozciąganie i ścinające naprężenia

\section{Streszczenie}

Wprowadzenie. Zęby wychylone doprzedsionkowo stanowia problem estetyczny $i$ biomechaniczny. Czy odbudowa protetyczna zniszczonego zęba siecznego, którego korzeń jest wychylony dowargowo sprosta siłom żucia?

Cel pracy. Celem pracy była ocena wptywu wychylenia osi zębów przednich na wytrzymatość siekaczy odbudowanych wktadami koronowo-korzeniowymi.

Material i metody. Badanie przeprowadzono metoda elementów skończonych z użyciem elementów kontaktowych. Stworzono modele 3-D zęba siecznego przyśrodkowego szczęki: model $A$ - zab; model B - ząb z wktadem i korona. Osie modeli siekaczy A i B zostaty ustawione 1 - dopodniebiennie (kat inklinacji 10), 2 - prawidtowo (kat inklinacji 30॰); 3 - dowargowo (kat inklinacji $50^{\circ}$ ). Każdy model obciażono siła $100 \mathrm{~N}$. Do oceny wytężenia struktur zębów i cementu zastosowano zmodyfikowane kryterium Misesa. 
cement-tissue interface adjacent to prosthetic restorations were calculated.

Results. The lowest reduced stresses were recorded for the palatally inclined incisors (model A1). In the dentine of the labially inclined incisor (model A3), the mvM stresses were up to $80 \%$ higher in comparison with the normally inclined incisor (A2). In the proclined anterior tooth with a post and core restoration (B3), the value of equivalent contact stresses increased by more than a half in relation to the properly positioned model B2. The concentration of stresses occurred on the palatal side of the tooth cervix. In the post and core, Von Mises stresses of $100 \mathrm{MPa}$ were noted.

Conclusions. The equivalent stresses in the structures of incisors increase with the proclination of the tooth axis. In inclined anterior teeth restored with post and cores there occurred significantly higher and unfavourably distributed stresses than in normally positioned teeth. Post and core build-up of proclined incisors have a higher predisposition to debonding of the restoration, bending of the post, or even fracture of the root.

\section{Introduction}

Labial or palatal incisor inclination is related to their angle to the bone base. According to Steiner's cephalometric analysis, it is assumed that the inclination of the maxillary central incisors in relation to the NA ( 1 :NA) line should be $22^{\circ}$, while the inclination of the mandibular central incisors in relation to the NB (1:NB) line should be $25^{\circ} .{ }^{1}$ In skeletal Class I, Jacobson's Wits appraisal, which is determined by the projections of points $\mathrm{A}$ and $\mathrm{B}$ on the functional occlusal plane (FOP), should equal $0 \mathrm{~mm} .^{2}$ The axial inclination of the teeth in relation to the occlusal plane for maxillary incisors is $60^{\circ}$, and $72^{\circ}$ for mandibular incisors. ${ }^{3}$ However, according to Wheeler, the average axial inclination is $62^{\circ}$ and $68^{\circ}$, respectively. ${ }^{4}$
Obliczono naprężenia rozciagajace $i$ ścinajace $w$ połaczeniu cementu z tkankami wokół uzupetnień protetycznych.

Wyniki. Najniższe naprężenia zredukowane wystapity w siekaczu wychylonym dopodniebiennie (model A1). $W$ zębinie zęba wychylonego protruzyjnie (model A3) naprężenia mvM wzrosty aż o $80 \%$ w stosunku do siekacza prawidłowo położonego (A2). W zębie siecznym wychylonym dowargowo i odbudowanym wktadem $k k$ (model B3), wartości naprężeń byty większe o ponad połowę $w$ porównaniu do zęba o prawidlowej inklinacji. Koncentracja naprężeń zredukowanych $i$ kontaktowych wystapita po stronie podniebiennej, wokót szyjki zęba. W wktadzie powstaty naprężenia von Mises o wartości $100 \mathrm{MPa}$.

Wnioski. Naprężenia zredukowane mvM w strukturach zębów siecznych rosna wraz z wychyleniem doprzednim osi tych zębów. W zębach przednich wychylonych dowargowo i odbudowanych wktadami kk, powstaja znacznie większe, niekorzystnie rozłożone naprężenia $w$ porównaniu do zębów prawidtowo położonych. Odbudowa wktadem koronowo-korzeniowym wychylonego doprzednio zęba jest narażona na odcementowanie i zgięcia wktadu lub nawet złamanie korzenia.

According to Tong at al., the inclination of maxillary central incisors to vertical plane is the highest at $33.5^{\circ}$, and mandibular incisors which have an inclination of $26.5^{\circ} .5$ The incisors in Class II/division 1 malocclusion have significantly higher inclination angles. ${ }^{6}$

The interincisal angle defines the mutual axial inclination of the upper and lower incisors. It is assumed that this angle should ideally be $129-132^{\circ} .4,7$ The positioning of incisors is a determining factor for an aesthetic smile and proper lip support. It also affects the function of the stomatognathic system due to the fact that these teeth guide the mandible during protrusion.

Occlusal loading of substantially proclined anterior teeth can have a traumatic effect on the surrounding tissues. ${ }^{8}$ Higher inclination of anterior teeth results in higher stress in the tooth, 


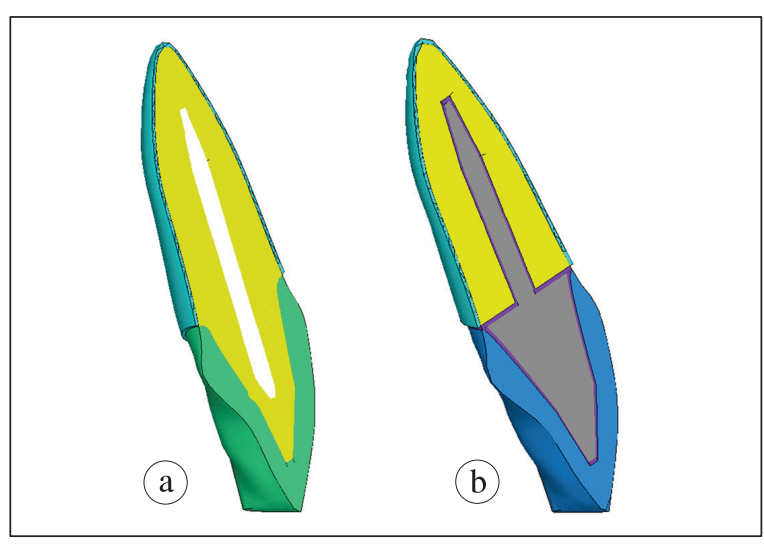

Fig. 1. Cross-sections of anterior teeth models; $a$-Model A - incisor tooth, $b-$ Model B - incisor restored with post and core and prosthetic crown.

periodontium and bone. Similarly, increasing the labial axial inclination of implants in the anterior region causes a significant increase in stress in the bone, which may result in treatment failure. ${ }^{9}$ In the case of implants, the inclination should not exceed $20^{\circ} .10$

Incorrect inclination of teeth that are in the ectopic position in the dental arch should be orthodontically treated. Prosthodontic restorations can be considered in cases where inclined incisors have significant coronal damage but have undergone proper endodontic treatment. In these cases individual post and cores with prosthetic crowns are used. However, will such a restoration withstand masticatory forces? Will the restoration last? What is the effect of labial or palatal inclinations of incisors on stress distribution in tissues and prosthodontic restoration?

The aim of the study was to estimate the influence of labiolingual anterior teeth inclination on the strength of incisors reinforced with post and cores.

\section{Materials and methods}

The study was carried out using the finite element method (FEM). The scans of the surface of the maxillary central left incisor were

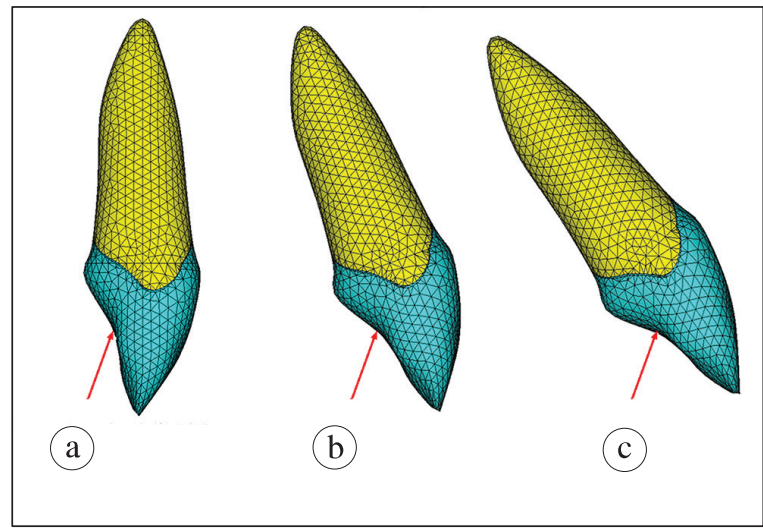

Fig. 2. Various inclinations of incisors (model A) under occlusal loading; a -Model A1 - tooth with inclination $10^{\circ}, b-$ Model $A 2$ - tooth with inclination $30^{\circ}, c-$ Model A3 - tooth with inclination $50^{\circ}$.

obtained using the laser Dental 3D Scanner D250 (3ShapeA/ S, Copenhagen, Denmark). In addition, a CT scan of the investigated tooth was made with a GXCB-500/i-CAT system(Gendex Dental Systems, Des Plaines, IL, USA). The coordinates of points on the tooth surface and on the enamel-dentine junction were introduced into the FEA software - ANSYS 18 (ANSYS version 18, ANSYS Inc., Canonsburg, PA, USA). ${ }^{11}$ They were connected. On this basis, a solid model of the central incisor, divided into enamel, dentine and pulp was created (model A) (Fig. 1a), similar to previous studies. ${ }^{12}$ A 0.2 mm thick periodontium was modelled around the tooth root.

The maxillary central incisor was prepared for a ceramic crown. The prepared tooth was scanned using Dental 3D Scanner D250. A cloud of points of abutment surfaces was introduced into the ANSYS program. Then, in software a $8.5 \mathrm{~mm} \times 1.2 \mathrm{~mm}$ cylinder with a blunt cone at the end was generated. This solid was introduced into the root canal and then added to the tooth model. In this way, a tooth model with a post and core and a prosthetic crown was created (model B) (Fig. 1b). ${ }^{13}$ A $0.1 \mathrm{~mm}$-thick layer was added around the root part of the post, as well as under the crown, to imitate the layer of the luting cement. 

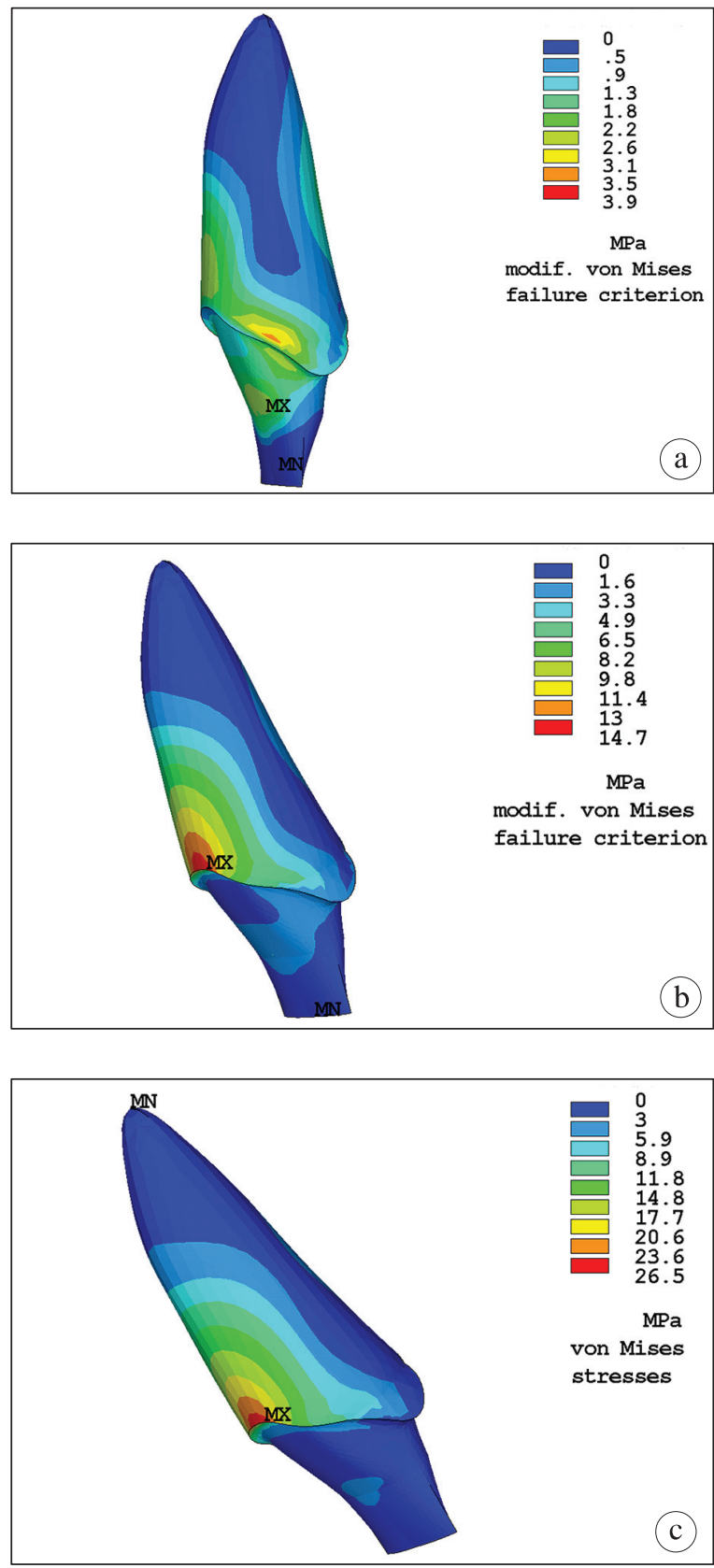

Fig. 3. Distribution of equivalent von Mises stresses $(m v M)$ in dentine of model $A$ with various inclinations (MPa); a-Model A1, b-Model A2, $c$-Model A3.

Each tooth model was divided into 10-node structural solid elements (Solid 187). Model A was divided into approximately 71.000 elements, connected in 98.500 nodes. In model B with post and core, 118.000 elements joined in ca. 134.000 nodes were used. Pairs of bonded contact elements Targe 170 and Conta 174, were used around the posts and at the cementdentine interface. Each of the models was fixed in nodes on the external surface of the periodontium, to simulate fixing the tooth with periodontium in the bone.

Three different cases of spatial orientation of the incisors were examined. Models A and $\mathrm{B}$ were placed in proper anatomical position ( $30^{\circ}$ to the vertical plane). ${ }^{7}$ The models were subjected to loads simulating forces acting on incisors during clenching in the centric occlusion. Their total value was $100 \mathrm{~N},{ }^{14}$ and they were applied under the lingual cingulum of a crown, at an angle of $45^{\circ}$ to the longitudinal axis of the tooth (model A2 and B2) (Fig. 2b). Then, retroclination of incisors was simulated and axes of the models were inclined $10^{\circ}$ to the vertical plane. Mastication forces acted on these models at an angle of $25^{\circ}$ to their longitudinal axes (models A1 and B1) (Fig 2a). In the next stage, proclination of the incisors was simulated, model teeth were labially inclined at $50^{\circ}$ and were loaded at an angle of $65^{\circ}$ to the longitudinal axis of the tooth (models A3 and B3) (Fig. 2c).

It was assumed that the post and core was made of $\mathrm{Au}$ alloy, ${ }^{15}$ and that the crown had ceramic properties. ${ }^{16}$ The restorations were bonded to the structure of the tooth using resin cement. ${ }^{17}$ The elasticity modulus and Poisson ratio values for enamel, ${ }^{18}$ dentine, ${ }^{19}$ periodontium ${ }^{20}$ were introduced (Table 1). It was assumed that the materials used in the model were linear, elastic, homogenous and isotropic, but had different compressive and tensile strength values: enamel $\left(11.5 \mathrm{MPa},{ }^{21}\right.$ $384 \mathrm{MPa}^{22}$ ), dentine (105.5MPa, $\left.{ }^{23} 297 \mathrm{MPa}^{22}\right)$, ceramic $(48.8 \mathrm{MPa}, 162.9 \mathrm{MPa}),{ }^{24}$ resin cement (45.1MPa, $178 \mathrm{MPa}),{ }^{25}$ except gold alloy (457 $\mathrm{MPa}) .^{15}$

Equivalent stresses in models at different loads were calculated. The modified von Mises failure criterion (mvM) was used to assess the failure (under complex stress conditions) of 
Table 1. Data of materials used in models

\begin{tabular}{|l|c|c|c|c||}
\hline \multicolumn{1}{|c|}{ Material } & $\begin{array}{c}\text { Modulus of } \\
\text { elasticity [GPa] }\end{array}$ & Poisson ratio & $\begin{array}{c}\text { Ultimate tensile } \\
\text { strength [MPa] }\end{array}$ & $\begin{array}{c}\text { Ultimate } \\
\text { compressive } \\
\text { strength [MPa] }\end{array}$ \\
\hline Enmel & 84.1 & 0.33 & 11.5 & 384.0 \\
\hline Dentine & 18.6 & 0.31 & 105.5 & 297.0 \\
\hline Periodontium & $3 \times 10^{-5}$ & 0.45 & & \\
\hline Gutta-percha & 0.14 & 0.40 & & 162.9 \\
\hline AuCuAgPd alloy & 96.6 & 0.30 & 450.0 & 178.0 \\
\hline Leucite ceramic & 65.0 & 0.19 & 48.8 & \\
\hline Resin cement & 8.3 & 0.35 & 45.1 & \\
\hline
\end{tabular}

Ta b le 2. Maximal values of modified von Mises stresses (mvM) in incisors models at different inclinations

\begin{tabular}{|c|c|c|}
\hline \multirow{2}{*}{ Tooth model } & \multicolumn{2}{|c|}{ Maximal equivalent stresses mvM (MPa) } \\
\cline { 2 - 3 } & Enamel & Dentine \\
\hline Model A1 $\left(10^{\circ}\right.$ inclination $)$ & 18.7 & 3.9 \\
\hline Model A2 $\left(30^{\circ}\right.$ inclination $)$ & 22.2 & 14.7 \\
\hline Model A3 $\left(50^{\circ}\right.$ inclination $)$ & 25.3 & 26.5 \\
\hline
\end{tabular}

the tooth tissues, ceramic and resin cement. ${ }^{26}$ The von Mises failure criterion was to evaluate the effort of the Au alloy (because the tensile and compressive strength for metals are comparable). The results of the equivalent stresses were presented as maps of these stresses distributions in the materials of the incisor models. Compressive, tensile, and shear contact stresses at the cement-dentine interface around posts and under the crown were also calculated and graphically presented.

\section{Results}

The maximal values of mvM stresses occurring in the incisor models (models A) with different degrees of inclination are presented in Table 2. The highest mvM stresses in the materials of incisors restored with post and cores and crowns (models B), with different inclination, are summarized in Table 3. The maximal values of tensile and shear stresses in models $\mathrm{B}$, around prosthetic restorations, at the cement-dentine interface, are presented in Table 4.

In the $\mathrm{A} 2$ tooth model, the maximum mvM stresses in enamel amounted to $22.2 \mathrm{MPa}$, and 14.7 MPa in dentine (Fig. 3) (Table 2). In the A3 model (proclined incisor), the equivalent stresses in dentine increased by $80 \%$ to 26.5 $\mathrm{MPa}$. However, in the A1 model (retroclined incisor), the equivalent stresses in dentine decreased by $73 \%$ to $3.9 \mathrm{MPa}$ (Fig. 3). With increasing proclination of the tooth, greater mvM stresses were observed palatally in the CEJ area, in dentine and in enamel. 
Ta b le 3. Maximal values of modified von Mises stresses (mvM) in incisors models of different inclination. restored with posts and cores

\begin{tabular}{|c|c|c|c|c|}
\hline \multirow{2}{*}{ Tooth model } & \multicolumn{4}{|c|}{ Maximal equivalent stresses in the materials of models (MPa) } \\
\cline { 2 - 5 } & Post & Crown & Dentine & Cement \\
\hline Model B1 (10 inclination) & 45.4 & 15.1 & 7.0 & 5.1 \\
\hline Model B2 (30 inclination) & 67.3 & 15.6 & 15.6 & 14.1 \\
\hline Model B3 (50 inclination) & 99.7 & 18.0 & 24.5 & 23.7 \\
\hline
\end{tabular}

Tab le 4. Maximal values of contact stresses in cement-dentine interface, under restorations, in incisors models at different inclinations, restored with posts and cores

\begin{tabular}{|c|c|c|c|}
\hline \multirow{2}{*}{ Tooth model } & \multicolumn{3}{|c|}{ Maximal contact stresses in models (MPa) } \\
\cline { 2 - 4 } & Compressive & Tensile & Shear \\
\hline Model B1 $\left(10^{\circ}\right.$ inclination $)$ & 9.8 & 1.7 & 2.9 \\
\hline Model B2 $\left(30^{\circ}\right.$ inclination $)$ & 12.4 & 10.6 & 3.0 \\
\hline Model B3 $\left(50^{\circ}\right.$ inclination $)$ & 16.7 & 15.3 & 4.6 \\
\hline
\end{tabular}

In the B2 tooth model (correct position of incisor with post and core), the mvM stresses in dentine were 15.6 MPa (Table 3). In metal post and core, the von Mises stresses reached a value of 67.3 MPa at the post-core junction. The mvM stresses in the luting resin cement had a value of 14.1 MPa. Contact tensile stresses at the cement-dentine interface, under post and core reached a value of $10.6 \mathrm{MPa}$, while shearing stresses were $3.0 \mathrm{MPa}$ (Table 4).

In the B3 tooth model (Fig. 4) (proclined incisor with post and core), the stresses increased significantly in comparison to B2 models. In dentine, the mvM stresses reached a value of $24.4 \mathrm{MPa}$ (increased by $57 \%$ ), while in cement they were at $23.7 \mathrm{MPa}$ (increased by $68 \%$ ) (Table 3 ). Higher concentration of mvM stresses in dentine, cement, and crown occurred palatally at the CEJ. In the post-core, the von Mises stresses reached a value close to $100 \mathrm{MPa}$. Contact tensile stresses between the bearing surface of the tooth and the core, on the palatal side, increased to $15.4 \mathrm{MPa}$ (increase of $44 \%$ ), while tensile stresses increased to 4.6 $\mathrm{MPa}$ (increase of 53\%) (Table4).

However, in the B1 model (Fig. 5) (retroclined incisor with post and core), the stresses decreased in relation to the B2 model. A reduction of more than half occurred in dentine, in cement it was lower by $64 \%$, and in the post and core by $33 \%$ (Table 3 ). Contact tensile stresses decreased by $84 \%$ (Table 4 ).

\section{Discussion}

The study showed that the inclination of the longitudinal axis of the incisor in relation to the direction of masticatory forces is of great importance for strength of tooth structures. The highest mvM stresses in tooth tissues and restorations were observed in proclined incisors, while the lowest ones were observed in retroclined incisors. The equivalent stresses in proclined teeth were concentrated palatally around the CEJ, and were $80 \%$ greater in dentine than in the properly positioned teeth. 

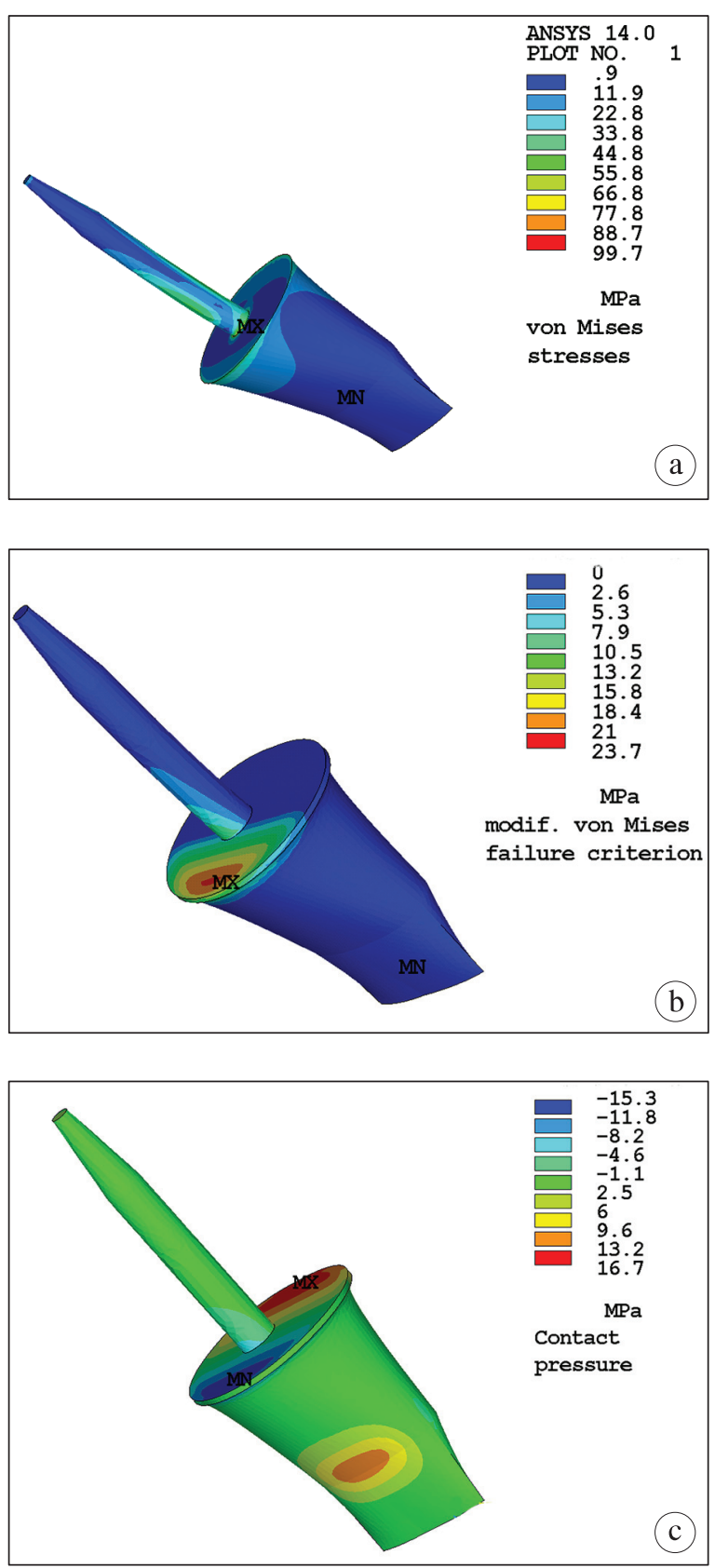

Fig. 4. Distribution of equivalent stresses in model B3 - tooth labially inclined, restored with post and core (MPa); von Mises stresses in metal post, $m v M$ stresses in luting cement, contact tensile and compressive stresses in the cement-dentine bonding interface (maximal contact tensile stresses values are indicated by dark blue colour).

Similar results have been achieved by a study conducted by Gerami et al., ${ }^{8}$ which showed that increasing the labial angle of the mandibular central incisors resulted in much higher cervical
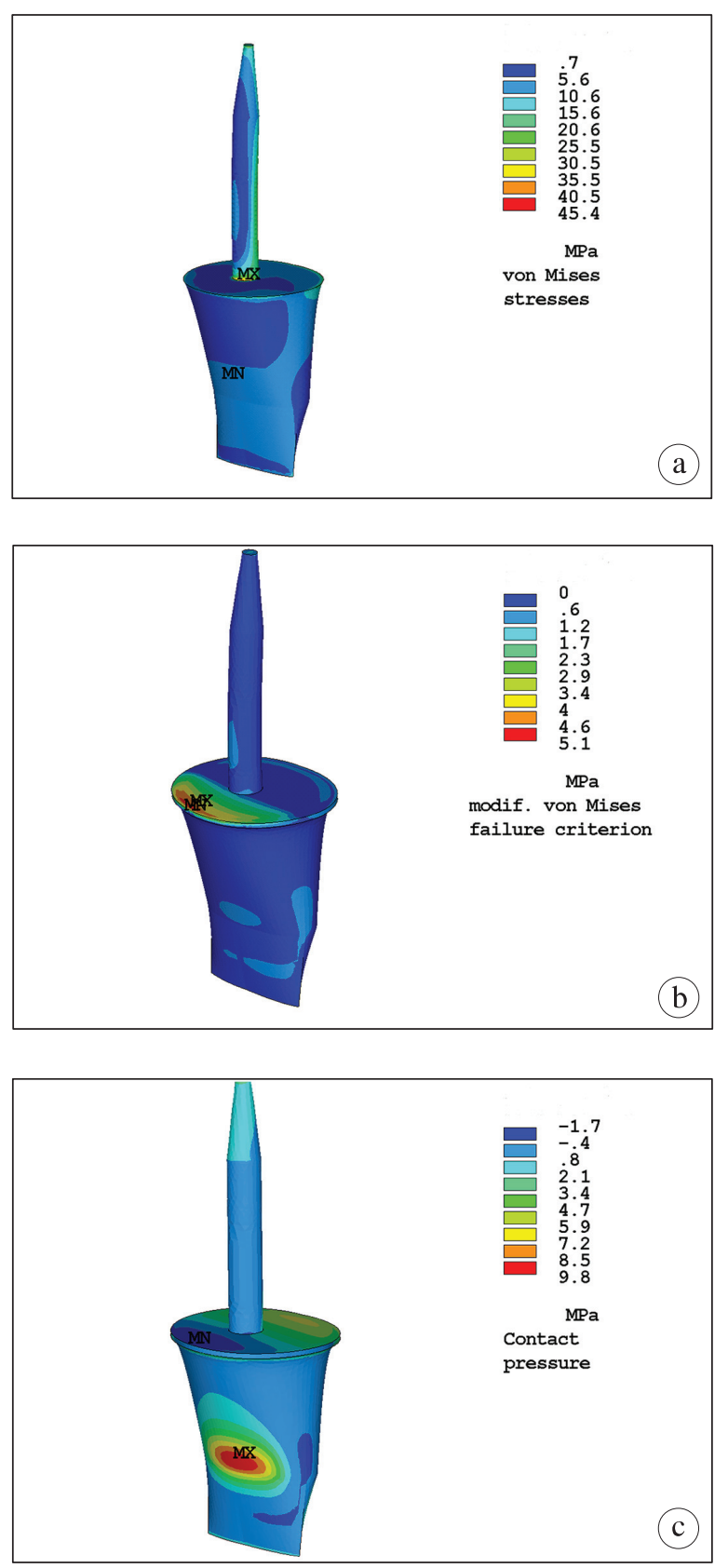

Fig. 5. Distribution of equivalent stresses in model B1 - tooth palatally inclined, restored with post and core (MPa); von Mises stresses in metal post, $m v M$ stresses in luting cement, contact tensile and compressive stresses in the cement-dentine bonding interface (maximal contact tensile stresses values are indicated by dark blue colour).

stresses in splinted and tilted teeth under occlusal loads. This situation may produce a cervical tooth fracture.

Excessive proclination is particularly 
dangerous for prosthetically restored incisors. In tooth models with labial inclination, significantly higher mvM stresses and contact stresses around the post and cores were observed than in properly positioned teeth. Equivalent stresses were concentrated palatally around the tooth cervix, in dentine, post and cores, and luting cements. Contact tensile and shear stresses arise palatally, between the core and the bearing surface of dentine. Labial inclination of incisors will adversely affect the strength of teeth restored with post and cores. This situation may cause debonding of the restoration, microleakage, bending of the post and core or even fracture of the root. Clinical observations confirm that maxillary central incisors with labial inclination that were restored with metal cast post-cores are prone to fractures. ${ }^{27}$ Several researchers suggest using FRC posts instead of alloy ones. Unfortunately, this type of restoration does not guarantee longterm success, either. ${ }^{27}$

Previous strength tests conducted on anterior teeth with large inclination angles focused primarily on orthodontic problems. The application of additional loads to the proclined tooth caused a significant increase in stresses in its structures, in the periodontium, and bone. According to a study conducted by Sung-Hwan et al., ${ }^{28}$ an increase in labial inclination of the tooth caused an increase in stresses. Similarly, Kanjanaouthai et al. ${ }^{29}$ observed that there were tensile stresses around the root, and more compressive stresses concentrated at the apex of incisors with a high degree of inclination. This may be associated with a higher clinical incidence of apical root resorption of these teeth.

Unfavourable situations also arise upon the loading of proclined implants. Increasing the inclination of the applied force relative to the long axis of the implant tended to overload the peri-implant bone tissue and the internal structure of the implants. ${ }^{30}$ The higher angle of inclination of implants in the anterior region caused a significant increase in tensile stresses in the bone surrounding the implants. Tensile stress values partially surpassed the yield strength of the cortical bone, especially when a $20^{\circ}$ inclination was applied for fixture placement. ${ }^{31}$ Implants are rigidly connected to bone. The absence of PDL had detrimental effects on the surrounding bone because the applied stress remained concentrated at the bone crest and the cervical third of the root. PDL with a lower elastic modulus can help protect the alveolar bone crest from stress concentration. ${ }^{32}$

This study demonstrates that increasing the inclination of anterior teeth can mostly harm the central incisors, not only for periodontal or orthodontic reasons. Prosthetic restoration of such teeth may be subject to destruction, regardless of the beneficial periodontal effect in natural teeth. Therefore, when restoring damaged structures of anterior teeth which have an labial inclination, particular attention should be paid to providing proper occlusal support of posterior teeth, and thus relieving incisors of occlusal loading.

\section{Conclusions}

Within the limitation of this study:

1. The mvM stresses in structures of incisors increase with the proclination of the tooth axis. Labial inclination of incisors causes an increase of stresses in tooth hard tissues, while palatal inclination reduces the stresses when compared to properly positioned teeth.

2. In proclined incisors restored with post and cores, significantly higher and unfavourably distributed stresses occurred when compared to normally positioned anterior teeth. Prosthetic reconstructions of proclined incisors have a higher predisposition to debond, the post to bend, or the root to fracture. 


\section{References / Piśmiennictwo}

1. Kowalski CJ, Walker GF: The use of incisal angles in the Steiner cephalometric analysis. Angle Orthod 1972; 42: 87-95.

2. Jacobsen A: The "Wits" appraisal of jaw disharmony. Am J Orthod 1975; 66: 125-138.

3. Wiliams $S$, Loster $B$ : Cephalometrics rationalised: Presenting the Kracovia Composite System (KCS). J Stomatol 2012; 65, 4: 525-542.

4. Ash M, Nelson $S$ : Wheeler's dental anatomy, physiology and occlusion. 8 ed. Philadelphia: Saunders Co.; 2003. p. 297-314.

5. Tong H, Kwon D, Shi J, Sakai N, Enciso R, Sameshima GT: Mesiodistal angulation and faciolingual inclination of each whole tooth in 3-dimensional space in patients with nearnormal occlusion. Am J Orthod Dentofacial Orthop 2012; 141: 604-617.

6. Kirschneck C, Römer P, Proff P, Lippold C: Association of dentoskeletal morphology with incisor inclination in angle class II patients: a retrospective cephalometric study. Head Face Med 2013; 3: 24.

7. Kraus B, Jordan R, Abrams L: Dental anatomy and occlusion. Baltimore: Williams \& Wilkins Co; 1969. p. 227.

8. Gerami A, Dadgar S, Rakhshan V, Jannati P, Sobouti F: Displacement and force distribution of splinted and tilted mandibular anterior teeth under occlusal loads: an in silico 3D finite element analysis. Prog Orthod 2016; 17: 16.

9. Hsu ML, Chen FC, Kao HC, Cheng CK: Influence of off-axis loading of an anterior maxillary implant: a 3-dimensional finite element analysis. Int $\mathrm{J}$ Oral Maxillofac Implants 2007; 22: 301-309.

10. Han LH, Qiu XX, Xing XN, Cai LY: Finite element analysis of the angulation designment of implant planning in the anterior maxilla. Shanghai Kou Qiang Yi Xue 2015; 24: 157163.
11. Zienkiewicz $O$, Tylor R: Finite element method. Volume1. The basis. 5 ed. Oxford: Butterworth-Heinemann; 2000, p. 87-110.

12. Dejak B, Młotkowski A: Finite element analysis of strength and adhesion of cast posts compared to glass fiber-reinforced composite resin posts in anterior teeth. J Prosthet Dent 2011; 105: 115-126.

13. Dejak B, Młotkowski A: The influence of ferrule effect and length of cast and FRC posts on the stresses in anterior teeth. Dent Mat 2013; 29: e227-e237.

14. Fontijn-Tekamp FA, Slagter AP, Van der Bilt A, Van THol MA, Witter DJ, Kalk W, Jansen $J A$ : Biting and chewing overdentures, full dentures and natural dentitions. J Dent Res 2000; 79: 1519-1524.

15. Oilo G, Gjerdet NR: Dental casting alloys with a low content of noble metals: physical properties. Acta Odontol Scand 1983; 41: 111-116.

16. Albakry M, Guazzato M, Swain M: Biaxial flexural strength, elastic moduli, and x-ray diffraction characterization of three pressable all-ceramic materials. J Prosthet Dent 2003; 89: 374-380.

17. Magne P, Perakis N, Belser U, Krejci I. Stress distribution of inlay-anchored adhesive fixed partial dentures: a element analysis of the influence of restorative materials and abutment preparation design. J Prosthet Dent 2002; 87: 516-527.

18. Habelitz S, Marshall S, Marshall G, Balooch $M$ : Mechanical properties of human dental enamel on the nanometre scale. Arch Oral Biol 2001; 46: 173-183.

19. Kinney JH, Marshall SJ, Marshall GW: The mechanical properties of human dentin: a critical review and reevaluation of the dental literature. Crit Rev Oral Biol Med 2003; 14: 13-29.

20. Rees JS, Jacopsen PH: Elastic modulus of the 
periodontal ligament. Biomaterials 1997; 18: 995-999.

21. Giannini M, Soares C, Carvalho R: Ultimate tensile strength of tooth structures. Dent Mat 2004; 20: 322-329.

22. Powers J, Sakaguchi R. Craig's restorative dental materials. 12th ed. St. Louis: Mosby; 2006. p. 61, 65 .

23. Sano H, Ciucchi B, Matthews W, Pashley $D$ : Tensile properties of mineralized and demineralized human and bovine dentin. J Dent Res 1994; 73: 1205-1211.

24. Probster L, Geis-Gerstorfer J, Kirchner E, Kanjantra $P$ : In vitro evaluation of a glassceramic restorative material. J Oral Rehabil 1997; 24: 636-645.

25. White $S, Y u$ Z: Compressive and diametral tensile strengths of current adhesive luting agents. J Prosthet Dent 1993; 69: 568-572.

26. De Groot R, Peters M, De Haan Y, Dop G, Plasschaert A: Failure stress criteria for composite resin. J Dent Res 1987; 66: 1748-1752.

27. Qian YM, Zhong Q, Chen S. Comparison of clinical effects of $\mathrm{Co}-\mathrm{Cr}$ alloy cast post-core and everStick fiber post in restoration of labially or lingually inclined maxillary central incisor. Shanghai Kou Qiang Yi Xue 2017; 26: 89-93.

28. Sung-Hwan C, Young-Hoon K, Kee-Joon L, Chung-Ju H: Effect of labiolingual inclination of a maxillary central incisor and surrounding alveolar bone losson periodontal stress: A finite element analysis. Korean J Orthod 2016; 46: 155-162.

29. Kanjanaouthai A, Mahatumarat $K$, Techalertpaisarn P, Versluis A. Effect of the inclination of a maxillary central incisor on periodontal stress: finite element analysis. Angle Orthod 2012; 82: 812-819.

30. Verri FR, Santiago JF Jr, Almeida DA, de Souza Batista VE, Araujo Lemos CA, Mello $C C$, Pellizzer EP: Biomechanical threedimensional finite element analysis of single implant-supported prostheses in the anterior maxilla, with different surgical techniques and implant types. Int J Oral Maxillofac Implants 2017; 32: e191-e198.

31. Sadrimanesh R, Siadat H, Sadr-Eshkevari P, Monzavi A, Maurer P, Rashad A: Alveolar bone stress around implants with different abutment angulation: an FE-analysis of anterior maxilla. Implant Dent 2012; 21: 196-201.

32. Chen WP, Lee BS, Chiang YC, Lan WH, Lin $C P$ : Effects of various periodontal ligament elastic moduli on the stress distribution of a central incisor and surrounding alveolar bone. J Formos Med Assoc 2005; 104: 830-838.

Zaakceptowano do druku: 22.01.2020 r.

Adres autorów: 92-213 Łódź, ul. Pomorska 251.

(C) Zarząd Główny PTS 2020. 